\title{
Financial Behavior of the Poor: A Case of Tea Growers and Pickers in Western Uganda
}

\author{
Bernard Wakabi Muhangi ${ }^{1}$, Oliver Schmidt ${ }^{2}$ \\ ${ }^{1,2}$ Mountains of the Moon University, School of Business and Management Studies, Fort Portal, Uganda
}

\begin{abstract}
Finding ways of helping the poor access financing and means to save and transfer money has been a preoccupation of many behavioural economists and researchers for many years. Understanding the financial behavior of the poor is therefore a crucial step towards finding ways of helping them to access cheaper financing and ways to save. This paper studies savings and money-transfer behaviours of small holder tea farmers and tea pickers in western Uganda. Recent works (especially from field experiments) on financial behviours of the poor are also explored. The paper concludes by stating that prospect theory is best placed to explain and predict savings behaviour of rural people.
\end{abstract}

Keywords: Financial behaviour, prospect theory, the poor, tea growers and pickers, Uganda

\section{Introduction}

The world is inhabited by so many poor people and increasingly, particularly due to population growth, they live in Sub-Sahara where this paperes case study is set. $60 \%$ of the rural African population live on less than USD 1.25 per day and $90 \%$ live on less than USD 2 per day [1]. It is noteworthy that Sub-Sahara-Africa ${ }^{e e}$ s poverty is projected to remain largely rural, whereas in other regions of the world poverty is changing from rural to urban [1].

In recent years, understanding the choices and incentives of the poor has emerged as a major research agenda of development economics. It studies the behaviours of people living under conditions of multi-faceted poverty considering beyond income among others health, education and community wellbeing [2].

To the backdrop of practical and medial ,surge e of interest in microfinance, there has been a particular focus on the financial behaviour of the poor [3], [4], [5]. It was found that there is a wide array of strategies and instruments that lowincome-households apply to manage their monies. Many of these studies are based on South Asia, the epicentre of microfinance, and on semi-urban settings. Yet, there is a significant difference in financial behaviours between rural and urban people, and between South Asia and Sub-Sahara Africa. While the fraction of population saving formally is almost the same, much more Africans than South-Asians save informally [5]. Moreover, the fraction of population using mobile phones to send and receive money is much higher in Sub-Sahara-Africa than in South Asia [6].

This paper adds to the literature on financial behaviour of the poor a comparative survey of small-holder tea-farmers and

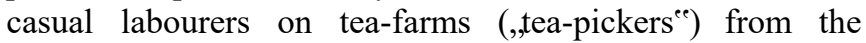
Rwenzori region in Western Uganda. It is organised as follows: Section 1 is the introduction; Section 2 gives an overview over the literature on financial behaviour of lowincome-households so far; Section 3 presents the theoretical framework. Section 4 presents the socio-economic profile of the Rwenzori region; Section 5 presents the findings from our survey; Section 6 concludes.

\section{Financial behaviour of the Poor}

Survey data from West Africa [7] and case studies from South Asia [8] show that poor people apply a variety of strategies to save, including savings collectors, who are paid for keeping the savings, and rotating and accumulating savings and credit associations (ROSCAs and ASCAs). Rutherford [8] became one of the most influential essays on financial behaviour of poor people, as it opened the microfinance debate among development aid agencies from credit-led to savings-led [9]. It was confirmed by Collins et..al [10] who studied financial behaviour in three countries (India, Bangladesh and [urban] South-Africa) through a large though statistically not representative set of financial diaries.

\subsection{Saving and Credit among the poor}

Savings mobilization is critical for individual and societal welfare. At the individual level, savings help households to smooth consumption and finance productive investments in human and business capital. At the macroeconomic level, savings rates are strongly predictive of future economic growth. Yet barriers to saving exist for many, particularly the world's poor. Market frictions, including transaction costs, lack of trust, and regulatory barriers, hinder the supply of savings products [11]. Only 22 percent of adults worldwide report having saved at a formal financial institution in the past 12 months, and 77 percent of adults living on less than $\$ 2$ a day report not having an account at a formal financial institution [6]. Mounting evidence also suggests that various demand-side constraints depress saving even among those with access. Social claimants, lack of knowledge, and/or behavioral biases may lead to suboptimal saving [11].

Despite these barriers, evidence suggests that the poor have substantial (latent) demand for savings. Household surveys indicate that the poor do have some surplus that they use for non-essential expenditures [12]. Similarly, detailed "diary" studies document complexity in poor householdse financial portfolios and highlight the demand for small irregular flows to be aggregated into lump sums for 


\section{International Journal of Science and Research (IJSR) \\ ISSN (Online): 2319-7064}

Index Copernicus Value (2013): 6.14 | Impact Factor (2014): 5.611

household or business investment [8],[10]. Even when formal savings products are unavailable or unaffordable, the poor often save under mattresses, pots, in informal groups, and/or in livestock (cows, goats, pigs, etc.). Some even go an extra mile to keep their savings with a trusted friend or relative. Microfinance institutions are often broadening their initial focus on microcredit to now include the provision of savings products.

Authors in [12] present a landmark paper on ,the economic lives of the poor ${ }^{\text {ee }}$ t turned into a book on the economics of poverty in 2011 [13]. It reports financial behaviour of households with a per capita income per day below USD 1.08 and USD 2.16 respectively (1993 purchasing power parity) for 13 countries with a particular focus on credit, savings and insurance:

- Credit: The poor borrow overwhelmingly from informal sources. Although their repayment performance is very good - one of the success factors of microfinance - their borrowing is very expensive (over $3 \%$ per month). Authors in [12] argue that it is driven by the cost of contract enforcement.

- Savings: Less than one in five poor hold a formal savings account, both rural and urban. Exceptions are Ivory Coast where almost 4 in 5 poor hold a formal savings account, and India, where five times more urban than rural poor have a formal savings account. Authors in [12] argue that low prevalence of savings is driven by lack of safe places. Authors in [14] support the same argument for the case of Uganda. Safety here refers both to the risk of the keeper stealing the savings, and the risk of the saver being tempted to spend the savings before achieving the initial savings objective.

- Insurance: There is virtually no market for formal insurance of the poor. They have evolved a wide variety of insurance-like mechanisms; mostly through informal credit with context-specific conditions, i. e. repayment and costing conditions relaxed based on the nature of the emergency. About 44 million Sub-Saharan lives and/or properties insured by microfinance insurance providers; over two third of them in Southern Africa [15].

Authors in [12] find from the review of the poores strategies for income generation and their spending behaviour on lownutrition foods, tobacco, alcohol and festive events that they could relatively easily increase their savings and thus accumulate wealth if they would reduce ,consumptive expenditures and invest more into their businesses or reduce their capital cost by reducing debt levels. From this raises the question ,why the poor do not save more ${ }^{e e}$, which has inspired a number of papers.

Several studies with experimental designs show significantly positive effects of savings on households, while studies on credit find at best very moderate effects [16].

Sub-Sahara Africa leads in the spread of mobile phone based financial services, for which M-Pesa (mobile money transfer through telephone network) in Kenya has become the most quoted example [17]. While there is little doubt that these technologies have the potential to greatly increase financial outreach, authors in [17] note that there is very little data on use of mobile phone based financial services by the poor.
Most studies are rather qualitative in nature [18]. Morawczynski \& Pickens [17] carried out a case study among rural poor Kenyans who use M-Pesa. They are usually convinced by their urban relatives to start using it as it is cheaper than alternative remittance channels. Their case study also observes that mobile phone based services are attractive as savings devices.

\section{Theoretical Framework}

This study is underpinned by the "Prospect theory" by Kahneman and Tversky [19]. Traditionally, it is believed that a desirable choice is made after an evaluation of the net effect of the gains and losses related to the choice. Behavioral economists tend to use "utility" to describe enjoyment and contend that people prefer instances that maximize their utility. However, evidence from research shows that people do not process information in such a rational way. The prospect theory contends that people value gains and losses differently and, as such, will base decisions on perceived gains rather than perceived losses. Thus, if a person were given two equal choices, one expressed in terms of possible gains and the other in possible losses, people would choose the former - even when they achieve the same economic end result.

According to prospect theory, losses have more emotional impact than an equivalent amount of gains. Phung [20] contends that in a traditional way of thinking, the amount of utility gained from receiving $\$ 50$ should be equal to a situation in which you gained $\$ 100$ and then lost $\$ 50$. In both situations, the end result is a net gain of $\$ 50$. However, despite the fact that you still end up with a $\$ 50$ gain in either case, most people view a single gain of $\$ 50$ more favorably than gaining $\$ 100$ and then losing $\$ 50$ [20]. For the poor, given the intensity in scarcity, face even a bigger challenge in trying to make rational choices. The issues of deciding how, where, and how much to save will always pose a challenge to the poor. The challenge is how to decide on the most optimal way to save or transfer money.

\section{Scope and Socio-Economic Background of Financial Services the Rwenzori region}

The Western-most region of Uganda is known by its characteristic mountain range; the Rwenzori Mountains, with Mount Margherita as Africaes s third-highest peak. They mark the border between the Congo basin to the West and the rift valley to the East. About $2.7 \mathrm{~m}$ Ugandans live in the region, out of which $0.25 \mathrm{~m}$ in the major urban agglomerations. The biggest town council of the region is Kasese with about $0.08 \mathrm{~m}$ inhabitants.

However, Fort Portal has more outlets of regulated financial institutions (FIs), probably because it is the region "s major hub for tourism. Thus, there are about 2.4 bank branches per 100,000 adults in the Rwenzori region, but 4.8 bank branches per 100,000 adults in the „Fort Portal region“ (i.e. Kabarole district). The major source of income is seasonal agriculture, such as growing cereals (mostly maize) and coffee; Bundibugyo (on the Western side of the Rwenzori 


\section{International Journal of Science and Research (IJSR) \\ ISSN (Online): 2319-7064}

Index Copernicus Value (2013): 6.14 | Impact Factor (2014): 5.611

mountains) grows cocoa. The dominant staple foods are plantains (matooke) which are home grown and harvested across all seasons. So are potatoes and other vegetables and life-stock (including apiary) and tea. The latter is the dominant cash crop in the Eastern parts of the region.

Rural poverty in Uganda has been reducing, mainly due to improved nutrition and reduced child mortality. Income poverty in Western Uganda has been reducing slower and inequality increased faster than the national trend.

Customer outreach of regulated MFIs is known to be very narrow. Author in [21] records that Microfinance institutions (MFIs) reach almost 2 out of 5 urban Ugandans but less than 1 out of 5 rural Ugandans. Savings and credit cooperatives (SACCOs) add about 0.5 out of 5 Ugandans to each rural and urban. Almost half of the rural and one quarter of urban of Ugandans relies on informal FIs (ROSCAs and ASCAs, money lenders including salary advances and purchase on credit from local shops); and one third does not use financial services at all.

A large number of SACCOs operates in the Rwenzori region. Many are plagued by severe governance and management issues. Many have collapsed, and some of those that are nominally in operations are stagnating or dysfunctional [22], [23].

Since 2005 , this has been compounded by politicization [9]. Others, particularly in semi-central market places where regulated FIs have not reached, are performing fairly well. These SACCOs have avoided affiliation with political agendas and have instead attracted steadily growing savings portfolios. Their loan products require less formal documents, particularly regarding collateral, than most regulated FIs [24]. They thus reach a segment of rural commercial-minded people who cannot satisfy their demand for financial services with regulated FIs. Noteworthy, the largest non-regulated FI in the Region is a church-based NGO-MFI (HOFOKAM), which has outlets in all central and many semi-central market places of the region and is therefore the major competitor of the locally operating SACCOs. It is known that many micro-loans are not used for business purposes, but for „consumption smoothening ${ }^{\text {ee }}$ [25], in particular paying school fees and steering through emergencies. Anecdotal evidence indicates that the same holds true in the Rwenzori region. As most people of the Rwenzori region are rural, it is obvious to assume that informal FIs, family members and, in house methodse (savings in a jar or in-kind and the like) are their first and foremost means of managing their monies between different points in time.

To this backdrop, FIs offer hardly any payment services or credit cards, and the limited features and exorbitant charges of regulated FIs and MFIs make them unattractive to the majority of people in the Rwenzori region; while SACCOs are viewed with widespread mistrust. It is a cash and in-kind economy where financial services are largely informal.

\section{Financial behavior of small holder tea famers and pickers in the Rwenzori region}

\subsection{Scope and composition of the data set}

This paper studies savings and money-transfer behaviours of tea growers and pickers in western Uganda. Although there have been a few initiatives on micro-insurance [26], non-life insurance remains largely elusive to most Ugandans. Authors in [27] give an optimistic outlook of recent changes in the policy framework, though. Life insurance has gained some coverage in form of loan insurance, because most of the larger MFIs in Uganda oblige borrowers to buy it. Savings, and to a certain degree money transfers, are thus a potentially important substitute for the lack of insurance. This paper neglects borrowing behaviour for two reasons. On the one hand, it can be thought of as mirroring savings

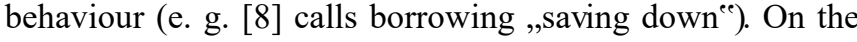
other hand, borrowing potential is related to savings potential and thus savings behaviour (e. g. access to credit is one important reason for saving among respondents of our survey).

The paper offers a comparative study of tea growers and casually employed tea pickers. In the Rwenzori region, farms are known as „gardens ${ }^{\text {ee }}$, casual labourers of the tea gardens are known as „tea pickers "e and owners of those gardens as „out-growerse". The latter are probably termed from the perspective of the 7 tea factories in Kabarole district that buy green leaf from these farmers, process it into dry tea and sell it through the Tea Auction in Mombasa (Kenya) [28].

Data for 100 out-growers, 37 tea pickers and 5 staff of a tea factory was collected in July 2011. Data for another 111 teapickers was collected in July 2012. The research tool was a structured questionnaire covering respondents ${ }^{\text {ee }}$ social status (marriage, age, household size etc.), income sources, expenditures and savings, borrowing and money transfer behaviours. The 2012-questionnaire is a streamlined version of the 2011-questionnaire; adjusted based on observations and experiences from the previous data collection and analysis, and based on the focus of the comparative analysis of financial behaviour.

In 2011 respondents were found based on randomized locations. I. e. the randomized units were tea delivery centres of the factory, located at distances between 2 and $25 \mathrm{~km}$ from each other. In 2012 respondents were chosen based on the groups that were on plugging duty on the factory-owned estate during the field work week.

The tea factory is by legal form a cooperative and owned by the out-growers interviewed [28]. It commissioned the first study with the objective of improving services of a SACCO formed by out-growers of the same factory and promoted by the factory ${ }^{e e}$ s management.

\subsection{Savings and money transfers}

$93 \%$ of out-growers and $97 \%$ of tea-pickers save in money. Out of those who save, the average monthly savings amount 


\section{International Journal of Science and Research (IJSR) \\ ISSN (Online): 2319-7064}

Index Copernicus Value (2013): 6.14 | Impact Factor (2014): 5.611

is US\$ 31.80 for out-growers and US\$ 12.12 for tea-pickers. I. e. the average out-grower saves about 2.5 times more than the average tea-picker.

However, the median savings amount for out-growers is lower than for tea-pickers, US\$ 5.60 against US\$ 8.00. That indicates that the distribution of savings volumes around the average is wider for the out-growers than for the tea-pickers.

The tea-pickers reported their currently accumulated savings amount which is on average US\$ 49.90. That is about 4 months worth of savings. For the out-growers this information is not available.

Author in [29] finds about double the accumulated savings amount for a sample of rural women from two Rwenzori districts. However, this amount represents about 32 months worth of savings. These women pursue a mix of income generating activities in agriculture (other than tea) and in trade; their group savings are cushions built up slowly over the long term, while tea-pickers target to save a comparatively large part of their income over a short period; most migrants return to their homes once a year.

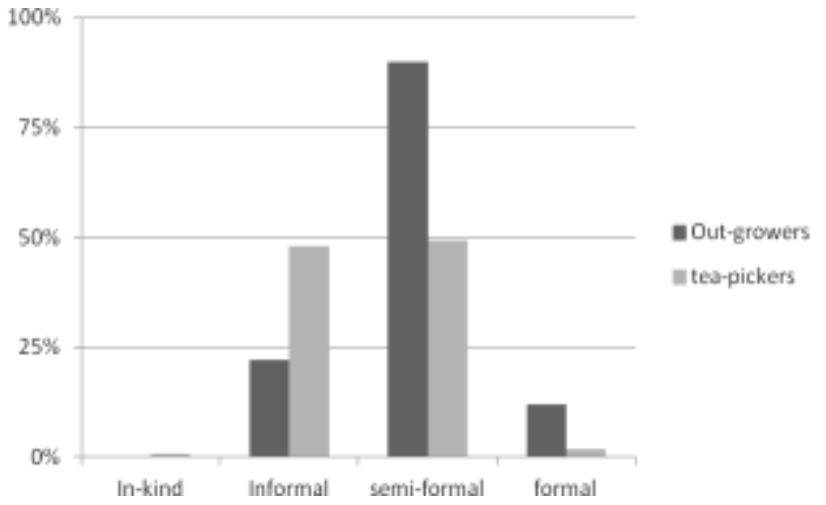

Figure 1: Savings by formality of location, out-growers and tea-pickers

Note: More than one location per respondent possible, therefore the sum per respondent class may exceed $100 \%$.

About 9 out of 10 out-growers save semi-formally (figure 1) by way of membership to the tea factory ${ }^{\text {ee }}$ SACCO. Out of the 14 respondents who indicate that they are members of another SACCO, all but 3 are also members of the tea factory ${ }^{e e}$ SACCO. Also, out of the 11 out-growers who bank formally, all but 2 are also members of the tea factory ${ }^{\text {ee }} \mathrm{s}$ SACCO. As for the tea-pickers, just about 5 out of 10 save semi-formally, and only 2 respondents bank formally. They are not members of a SACCO.

On the other hand, about half of the tea-pickers save informally (figure 1), out of which only 4 save in a SACCO. 1 tea-picker says he saves in-kind. As for the out-growers, only $22 \%$ save informally; half of them save also in a SACCO.

The purpose of saving for most out-growers is to take advantage of opportunities, i.e to accumulate ,usefully large sums $^{\text {ee }}$ [5]. The second most important reason is safeguarding against the (financial) impact of emergencies. Saving for the purpose of life-cycle-events takes third rank of importance (figure 2).

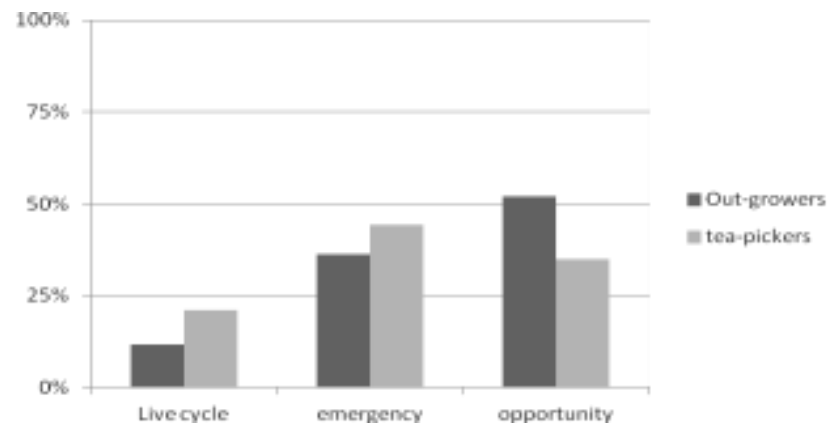

Figure 2: Purpose of savings, out-growers and tea-pickers

For the tea-pickers, the ranking is different, with safeguarding against the (financial) impact of emergencies being the most important, opportunities the second and lifecycle events the third most important (figure 2). The variance between the three is lower than among out-growers. Accordingly, life-cycle events are substantially more important a savings purpose for tea-pickers than for outgrowers.

\subsection{Money transfers}

$63 \%$ of out growers and $52 \%$ of tea-pickers own a mobile phone. However, only about 1 out of 3 out-growers with a mobile phone uses it for money transfers. For tea-pickers, the rate of mobile-phone based money transfers is only half of that of the out-growers.

Yet, $77 \%$ of tea-pickers regularly transfer money to their families, most of them on a monthly basis. Almost all of them send money through friends or use other informal channels. None of them uses Western Union. Mobile-phone based transfers are the exception.

Over all tea-pickers who transfer money regularly, the median amount transferred is US\$ 44.39. There is practically no correlation between savings and money-transfer amounts. Therefore, the money-transfers can largely be considered an addition to the savings discussed above.

By a distance, South African MTN is the major provider of mobile phone-based money-transfer services. However, other telephone companies (Indian Airtel, Ugandan UTL) have entered the market. Accordingly, all out-growers and most tea-pickers who use mobile-phone based money transfers are with MTN, but a few tea-pickers have chosen other companies.

\subsection{Why do respondents save/transfer monies the way they do?}

In the past, it had often been assumed, more or less implicitly, that being poor means not to have money to save. Authors in [8], [10] showed that this is not true. Their findings are supported by this survey of Western-Ugandan small scale tea-farmers (,out-growers") and their casual labourers (,tea-pickerse ${ }^{e}$ ). No matter how rich or poor, a person with no savings at all is a rare exception. 


\section{International Journal of Science and Research (IJSR) \\ ISSN (Online): 2319-7064}

Index Copernicus Value (2013): 6.14 | Impact Factor (2014): 5.611

Accordingly, correlation analysis between income and savings of our respondents yields no significant relationship. Furthermore, savings are hardly related to land size, the major asset in the case. Although the correlation coefficient stands at 0.3 , closer scrutiny shows that it is driven by a few outliers among the out-growers who own much more land and save much more than all others.

The relationship between household size, more specifically number of dependants, and savings could be of interest. The hypothesis is not straight forward, though. On the one hand, one might expect larger households to go with smaller savings amounts, because the regular expenses are higher. On the other hand, one might expect larger savings amounts, because larger households require, and supposedly foster, more complex money management and thus savings for school fees and health care.

Correlation analysis indeed is inconclusive, there is almost no correlation between out-growers ${ }^{e e}$ household size and monthly savings amount. Controlling for location of the household does not alter the result, i. e. tea-pickers from outside Kabarole or Uganda do not save systematically more than ,locals ${ }^{\text {ee }}$,i. e. Kabarole-based tea-pickers.

Further comparative scrutiny of local and migrant teapickers unveils that the average migrant earns more from his casual labour, i. e. picking tea, than the average local. Furthermore, he earns almost as much from other activities as the local, while spending less on food. The difference is not large, though. After food expenditure, income per day for the average local is 1.18 USD and for the average migrant 1.30 USD.

$89 \%$ of migrant casual labourers send money home, on average 32.04 USD per month. That is equivalent to $82 \%$ of the daily income after food expenditure. Even $66 \%$ of the local casual labourers send money home, on average 20.75 USD per month. That is equivalent to $59 \%$ of the daily income after food expenditure. The major difference between small-holder farmers and casual labourers is endowment with land.

The median land holding of the farmers is 0.7 acres per household member. The median landholding of the casual labourers is less than one third of that, just 0.25 acres per household member. This is despite the fact that the average household size of farmers is almost double that of the average household size of the casual labourers, 7.8 to 4.0. Indeed, household size is partly determined by landholding, indicated by a correlation coefficient of 0.34 over all respondents. Among smallholder farmers, household size in turn determines percentage of land cultivated with tea [30].

Land holding affects income, because it reduces monetary expenditure on food. However, as shown above, income is hardly determining savings behaviour. It could be argued that land and investment in land and maybe housing is a form of in-kind saving (,Saving brick by brick $\left.{ }^{e e},[2]\right)$. The research instrument did not probe into that explicitly, and thus respondents may not have considered it when responding to the question if they safe in-kind. This gap points to an area of investigation for future research.

People save because they have aspirations for the future. Table 1 shows the correlation coefficients between monthly savings amount and savings purpose. The correlation is substantial for the tea-pickers but not intuitive for the teagrowers.

Table 1: Correlation $\left(\mathrm{R}^{2}\right)$ of monthly savings amount and savings purpose

\begin{tabular}{|c|c|c|c|c|}
\hline & \multirow{2}{*}{\multicolumn{3}{|c|}{ Savings purpose }} \\
\hline & & & & \\
\hline & & $\begin{array}{l}\text { Life } \\
\text { cycle }\end{array}$ & Emergencies & Opportunities \\
\hline \multirow{2}{*}{$\begin{array}{l}\text { Monthly } \\
\text { savings } \\
\text { amount* }\end{array}$} & $\begin{array}{l}\text { Small scale } \\
\text { tea farmers }\end{array}$ & $-5 \%$ & $+14 \%$ & $-12 \%$ \\
\hline & \begin{tabular}{|c|} 
Casual \\
labourers (,tea \\
pickers"
\end{tabular} & $+19 \%$ & $+19 \%$ & $+24 \%$ \\
\hline
\end{tabular}

* Average constructed from savings amount and rhythm per place.

For tea-pickers, the purposes of savings ,life-cycle ${ }^{\text {ee }}$ and „emergency ${ }^{\text {ee }}$ respectively increase the likelihood of a higher monthly savings amount by $19 \%$. The purpose of savings „opportunities ee, increases the likelihood of a higher monthly savings amount by $24 \%$. If we think of the savings purpose as the motivating factor of monthly savings, this makes sense. Life-cycle and emergency are diffuse motivations; one being far away and the other being uncertain - moreover, humans prefer not to think about negative events [19]. Opportunities, on the other hand, are regularly rather tangible - moreover, they represent a reward towards which the ,unfun option ${ }^{\text {ee }}[31]$ of savings becomes bearable.

However, for tea-growing farmers, the purposes „life-cycle and ,opportunities ${ }^{\text {ee }}$ actually decrease the likelihood of a higher monthly savings amount. Those tea-growers who indicated to save for life-cycle are 5\% more likely to have a lower savings amount than those who do not save for lifecycle events; and those who indicate to save for opportunities are even $12 \%$ more likely to have a lower savings amount. Only emergencies might be considered a motivational factor to save more every month.

These counter-intuitive observations could be explained by;

- Risk aversion; tea-growers might be more risk averse than tea-pickers and they would thus be stronger motivated by emergencies than by opportunities. Indeed they appear to shy away from opportunities (in terms of mustering savings discipline); yet most of them gave opportunities as the savings purpose (see figure 2). Considering age and household size as indirect indicators of risk aversion, teagrowers indeed are on average older and have larger households than tea-pickers.

- Dishonest responses; people may intentionally or unintentionally have given wrong savings amounts or wrong purposes. Such might be indicated by the observation that most tea-growers, but not tea pickers, gave opportunities as savings purpose; yet tea-pickers seem to be more motivated by opportunities to save than tea-growers. 


\section{International Journal of Science and Research (IJSR) \\ ISSN (Online): 2319-7064}

Index Copernicus Value (2013): 6.14 | Impact Factor (2014): 5.611

- Constraints of data quality; many respondents did not or not consistently report the monthly savings amount and savings rhythm, and hence the monthly savings amount constructed on that basis might be slightly flawed.

For tea-pickers, different savings-variables are available (Table 2). This allows to probe into the consistency of the responses and may be an indicator for the honesty of the answers and quality of data respectively.

Table 2: Correlation $\left(\mathrm{R}^{2}\right)$ of savings purpose and different variables for savings amount (tea-pickers)

\begin{tabular}{|l|l|c|c|c|}
\cline { 3 - 5 } \multicolumn{2}{c|}{} & \multicolumn{3}{|c|}{ Savings purpose } \\
\cline { 3 - 5 } \multicolumn{2}{c|}{} & Life cycle & Emergencies & Opportunities \\
\hline \multirow{2}{*}{$\begin{array}{l}\text { Savings } \\
\text { amount }\end{array}$} & Last week & $+2 \%$ & $-5 \%$ & $+14 \%$ \\
\cline { 2 - 5 } & Monthly* & $+19 \%$ & $+19 \%$ & $+24 \%$ \\
\cline { 2 - 5 } & $\begin{array}{l}\text { Accumula } \\
\text { ted** }\end{array}$ & $+13 \%$ & $+3 \%$ & $+19 \%$ \\
\hline
\end{tabular}

* Average constructed from savings amount and rhythm per place.

** Savings stock at time of interview.

The correlation analysis across different variables for savings amount is highly consistent with the interpretation of savings purpose as important and effective motivator of savings behaviour.

Savings put aside last week are significantly more likely to be higher if motivated by an opportunity, which would be a concrete and rewarding target, probably achievable in the near future with the chosen savings amount. Live-cycle events and emergencies, on the other hand, were most likely diffuse last week. The likelihood to save a higher amount is low for life-cycle events - probably mainly those in the nearby future (such as school fees, the major life-cycle event highlighted by respondents) drive the positive $\mathrm{R}^{2}$. Emergencies even decrease the likelihood of saving more; which is consistent with people being concerned in general about emergencies but putting them off at the concretely given point in time, $i$. e. last week. It probably indicates that almost no respondent had a pressing emergency in the recent past.

Accordingly, monthly savings amounts are less likely to be higher for life-cycle events and emergencies than for opportunities. However all of them are positively correlated to the monthly savings amount, which is consistent with the responses reported in figure 2 , that all three savings purposes are of comparative importance.

Accordingly, the savings amounts accumulated are more likely to be higher for opportunities than for life- cycle events and emergencies. That is consistent with the understanding that opportunities are something tangible in the nearby future. In a more abstract view, one might expect a low correlation between savings stock and opportunities, because all respondents would be at different stages of saving up for, or drawing down on the opportunity.

Respondents indicate a positive correlation between savings stock and life-cycle events. Life-cycle events tend to be in the further-away future than opportunities, but they are more concrete than emergencies.

It is worrying, though, that the savings stock for emergencies - the cushion for the case that things go wrong - is rather unlikely to be high. Given the high prevalence of natural disasters affecting agricultural enterprises and of health issues affecting the average rural Ugandan, this indicates rather insufficient safeguarding (or inaccurate optimism). It also points to the double vulnerability of rural Ugandans: Not only are they more likely to lose income or to fall sick than their urban counter-parts, but when they do, they lose the savings stock that they had build up towards life-cycle events and opportunities.

\section{Conclusion}

This paper presents an inquiry into the financial behaviour of rural Ugandans whose income is sourced mainly from one crop, i. e. tea. Most of the respondents live in large households. Relatively larger land holding is positively correlated to household size. Accordingly, casual labourers have less land, if any, and smaller households. Some of the difference might be explained by casual labourers being on average younger than tea-growers. Thus, their motivation to work as tea-pickers is likely to acquire land and form families of their own or expand the same.

This motivation is reflected in the savings and money transfer behaviours. Interestingly, these behaviours are found to be hardly related to income and land size. They can be explained rather well by the savings purpose. Tea-pickerse savings appear to be strongly motivated by opportunities which includes purchase of land, as noted by some of the respondents - and to some degree by life-cycle events. The latter are, in this data-set, mainly school fees. Tea-pickers do not provide sufficiently for emergencies; and the thin cushion for emergencies puts the pursuit of opportunities and life-cycle plans at risk.

These findings are not borne out by the data-set for small scale farmers, though. The tea-growers appear to be much more risk-averse than the tea-pickers, and hardly motivated to save higher amounts for opportunities and life-cycle events. The differences could be partly explained by the social differences (age, household sizes, land holding) between the two respondent groups.

However, the tea-grower findings probably also point to flaws of the data-set: Many respondents did not give consistent information on the savings amounts and rhythms they apply in different places. That information forms the basis for constructing the monthly savings amount; hence it is not very accurate. Savings amount last week and accumulated savings stock at the time of interview are more reliable variables, but not available for the tea-growers.

It is remarkable that the tea-growers save much more in a SACCO (semi-formal) than the tea-pickers. While many SACCOs struggle to gain trust from their communities and convince them to join as members, this SACCO has been initiated and monitored by the tea factory to which the tea 


\section{International Journal of Science and Research (IJSR) \\ ISSN (Online): 2319-7064}

Index Copernicus Value (2013): 6.14 | Impact Factor (2014): 5.611

growers are associated. The positive effect of such access is visible in comparison to the tea-pickers. Tea-pickers, on the other hand, have hardly used mobile money for keeping savings or for transferring money, which underlines the impression in the literature that the fast growth of the mobile-phone based payment system in East Africa is yet to translate into poverty outreach.

In summary, the findings of this study, though nonexperimentally designed, strongly support the research agenda of behavioural economics; and indicate that prospect theory is best placed to explain and predict savings behaviour of rural people.

\section{References}

[1] IFAD, 2010, Rural poverty report, 2011.

[2] A. V.Banerjee, E. \& Duflo, Poor Economics: A Radical Rethinking of the Way to Fight Global Poverty, United States: Public Affairs, 2011.

[3] P. Dupas, S. Green, A. Keats \& J.Robinson.. "Challenges in Banking the Rural Poor: Evidence from Kenya"s Western Province", National Bureau of Economic Research, 2012.

[4] P. Dupas \& J. Robinson. "Savings Constraints and Microenterprise Development: Evidence from a Field Experiment in Kenya." American Economic Journal: Applied Economics 5 (1): 163-192, 2013.

[5] D. Collins, J. Morduch, S. Rutherford \& O.Ruthven, Portfolios of the Poor - How the World ${ }^{e e}$ s Poor Live on \$2 a Day, New Jersey, 2009.

[6] A. Demirgüç-Kunt, \& L. F. Klapper, "Measuring financial inclusion: The global findex database", World Bank Policy Research Working Paper, 2012.

[7] P. Shipton, "How Gambians save and what their strategies imply for international aid". World Bank Technical Report WPS 395, Washington D. C., 1990.

[8] S. Rutherford, The Poor and Their Money. Oxford University Press, New Delhi, 2000.

[9] O. Schmidt, "Uganda"s microfinance policy regime and exploration through a political-economy framework", [online]. Available: http://mpra.ub.unimuenchen.de/42374/1/MPRA_paper_42374.pdf, accessed $6^{\text {th }}$ Nov. 2015].

[10] S.Anderson \& Siwan, B.Jean-Marie "The Economics of Roscas and Intrahousehold Resource Allocation." Quarterly Journal of Economics 117 (3): 963-995, 2002.

[11]X. Gine, D. Karlan \& M. Ngatia, Social networks, financial literacy and index insurance, 2013

[12] A. V.Banerjee \& E, Duflo, "The Economic Lives of the Poor", Journal of Economic Perspectives, Vol. 21 (27), pp. 141-176, 2007.

[13]F. Meier zu Selhausen, \& J. M. Ruhweza, "The current performance of business and operations of rural Microfinance Institutions (MFIs) in the Rwenzori region", Rwenzori Journal, Vol. 1, pp. 77-99, 2011

[14] L. K. Mutesasira, \& G. A.Wright, "It Is Expensive to Be Poor: Losses Suffered by People Saving in Uganda", [online] www.microsave.org (Study Programme section), accessed: 21st Nov. 2015.

[15] T. Zeleke, Insurance for all, apresentado em MFW4A conference, Addis Ababa, 2011

[16]D. Roodman, "Latest Impact Research Inching towards Generalization", 2012, [online]: www.cgap.org/blog/latest-impact-research-inchingtowards-generalization, accessed: $18^{\text {th }}$ Dec. 2015.

[17] O. Morawczynski, \& M. Pickens, M. Poor People Using Mobile Financial Services: Observations on Customer Usage and Impact from M-Pesa, CGAP Brief, Aug. 2009, Washington D. C., 2009

[18] Grameen Foundation, "Stimulating innovation in the mobile money space for the benefit of the poor - the concept of savings as a deferred payment (Me2me)", in: Meier zu Selhausen, F. (ed), 2012

[19]D. Kahneman \& A. Tversky, "Prospect theory: An analysis of decision under risk" Econometrica: Journal of the Econometric Society, 263-291, 1979.

[20]A. Phung, " Behavioral Finance: Introduction. Investopedia. ValueClick, Inc., 2010.

[21]Uganda, Finscope. "Results of a national survey on demand, usage and access to financial services in Uganda." Kampala, Uganda, [online]: http://www. fsdu. or. ug/pdfs/Finscope_Report. pdf,2009.

[22] J. Robinson,. "Limited Insurance within the Household: Evidence from a Field Experiment in Kenya." American Economic Journal: Applied Economics 4 (4) (October): 140-164, 2012.

[23]C. Aheebwa, \& J. Brueggen, "The current Performance of Microfinance Associations (MFAs) in the Rwenzori Region", in: D. Karugaba, O. Schmidt, (eds.): Career Perspectives in Accounting, (Micro)Finance and other Sectors, Yearbook of MMU School of Business and Management Studies, Vol. 1, Fort Portal (MMU), 2010.

[24]R. Aliija, "MFIs" Agricultural Lending in the Ruwenzori region", in: Schmidt, O. (ed. 2012a): Proceedings of MMU's $1^{\text {st }}$ Microfinance Research Seminar, 25 ${ }^{\text {th }}$ May 2012, Fort Portal, [online]: http://mmumf.files.wordpress.com/2011/06/2012-07-12mf-research-seminar-proceedings-final2.pdf, accessed $15^{\text {th }}$ May 2015, pp. 13-17, 2012.

[25]O. Schmidt, "Die Illusionen der Mikrofinanz", Informationsbrief Weltwirtschaft \& Entwicklung, Vol. $09 / 2010$, S. 2-4, 2010

[26] C. Kilibo \& O. Schmidt, "Mitigating risks in Uganda", Development and Cooperation, Vol. 1/2006, [online]: www3.giz.de/E+Z/content/archive-eng/012006/foc art5.html, accessed: 24th Feb. 2013.

[27]P. Mukherjee \& S. P. Odele, "Micro-insurance in Uganda - tectonic shift in the near future?" MicroSave Briefing Note No. 120, April 2012, [online]: www.microsave.net, accessed: $24^{\text {th }}$ Feb. 2013.

[28] R. Siima, "Tea in the value chain", in D. Karugaba \& F. Meier zu Selhausen, (eds.): Regional and Political Economics, Yearbook of MMU School of Business and Management Studies, Vol. 2, pp. 49-56, 2011

[29] M. Kanyunyuzi, "Savings product design and women"s savings behaviour in rural areas - a case study of Villages Connected and Ric-Net", research report for the bachelor in banking and development finance 


\section{International Journal of Science and Research (IJSR) \\ ISSN (Online): 2319-7064}

Index Copernicus Value (2013): 6.14 | Impact Factor (2014): 5.611

(BBDF), Mountains of the Moon University, Fort Portal, 2013.

[30] MMU, "Rwenzori region in numbers", in: Yearbook of MMU's School of Business and Management Studies, edited by D. Karugaba and O.Schmidt, Vol. 1, pp. 127131,2010

[31]D. Karlan \& J. Appel, More Than Good Intentions: How a New Economics Is Helping to Solve Global Poverty, Penguin, New York, 2011

\section{Author Profile}

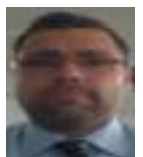

Dr. Schmidt has been working in development finance since 2004. He was part of the management of the national associations of microfinance in Uganda and India before joining Mountains of the Moon University (MMU) in Uganda in its endeavour to build a strong department for banking and microfinance. Since January 2013, he is the ag. Dean of MMU's School of Business and Management Studies. Dr. Schmidt has taught economics, international economics, monetary economics and microfinance in universities in Germany, the Netherlands, Uganda and India. He has trained over 200 microfinance practitioners from Burundi, India, Rwanda, Sri Lanka and Uganda. He has published various papers about microfinance, where his particular interests are governance and policy making, risk management, and education finance.

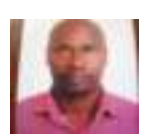

Bernard Muhangi Wakabi is a $\mathrm{PhD}$ student at Uganda Management Institute. He is a lecturer at Mountains of the Moon University, School of Business and Management Studies. He also doubles as the coordinator of Internships and Field placement. Bernard holds a Bachelor of Commerce degree from Makerere University and an MBA from Uganda Martyrs University. 